University of Wollongong

Research Online

Faculty of Engineering and Information

Faculty of Engineering and Information

Sciences - Papers: Part B

Sciences

2018

\title{
Factors Affecting the Bond Strength Between the Fly Ash-based Geopolymer Concrete and Steel Reinforcement
}

Mustafa Sameer Abdulkareem Al-azzawi

University of Wollongong, msaaa374@uowmail.edu.au

Tao Yu

University of Wollongong, taoy@uow.edu.au

Muhammad N. S Hadi

University of Wollongong, mhadi@uow.edu.au

Follow this and additional works at: https://ro.uow.edu.au/eispapers1

Part of the Engineering Commons, and the Science and Technology Studies Commons

Research Online is the open access institutional repository for the University of Wollongong. For further information contact the UOW Library: research-pubs@uow.edu.au 


\title{
Factors Affecting the Bond Strength Between the Fly Ash-based Geopolymer Concrete and Steel Reinforcement
}

\author{
Abstract \\ In this study, the effect of fly ash characteristics, the content of the fly ash and mix proportion of the Fly \\ Ash-Based Geopolymer Concrete (FBGC) on the bond strength between the FBGC and steel reinforcement \\ were examined. Australian fly ashes from five different sources (Eraring, Mt-Piper, Bayswater, Gladstone \\ and Collie) were used in producing FBGC. A total of 45 FBGC mixes with different fly ash content (300, \\ 400 and $500 \mathrm{~kg} / \mathrm{m}^{3}$ ) and different proportions of alkaline activator were prepared. The use of different fly \\ ashes and in different amounts showed significant differences in the bond strength between the FBGC \\ and steel reinforcement. It was found that the fly ash characteristics including particle size distribution \\ and the content of $\mathrm{SiO}_{2} \mathrm{Al}_{2} \mathrm{O}_{3}$ and $\mathrm{CaO}$ influenced the bond strength of the $\mathrm{FBGC}$ significantly. The results \\ showed that the FBGC that was mixed with Gladstone (GL) fly ash exhibited the highest average bond \\ strength between the FBGC and steel reinforcement (25 MPa). While the FBGC that was mixed with \\ Bayswater (BW) fly ash showed the lowest average bond strength between the FBGC and steel \\ reinforcement (10 MPa). The results also indicated that the increase in the fly ash content in the FBGC \\ significantly increased the bond strength between the FBGC and steel reinforcement. The bond strength \\ of the FBGC responded differently to changes in the $\mathrm{Na}_{2} \mathrm{SiO}_{3} / \mathrm{NaOH}$ ratio in the alkaline activator \\ corresponding to the use of different fly ash. \\ Disciplines \\ Engineering | Science and Technology Studies

\section{Publication Details} \\ Al-Azzawi, M., Yu, T. \& Hadi, M. N. S. (2018). Factors Affecting the Bond Strength Between the Fly Ash- \\ based Geopolymer Concrete and Steel Reinforcement. Structures, 14 262-272.
}

This journal article is available at Research Online: https://ro.uow.edu.au/eispapers1/1215 
1 Factors affecting the bond strength between the fly ash-based geopolymer concrete and

$5{ }^{1} \mathrm{PhD}$ Candidate, School of Civil, Mining and Environmental Engineering, University of Wollongong, Australia

${ }^{2 *}$ Associate Professor, School of Civil, Mining and Environmental Engineering, University of Wollongong, Australia

${ }^{3}$ Associate Professor, School of Civil, Mining and Environmental Engineering, University of 10 Wollongong, Australia

12 Correspondence:

13 Muhammad N. S. Hadi

14 School of Civil, Mining \& Environmental Engineering

15 University of Wollongong, Australia

16 E-mail:mhadi@uow.edu.au

17 Telephone: + 61242214762

18 Facsimiles: + 61242213238

19

$20 *$ Corresponding author 
21 Factors affecting the bond strength between the fly ash-based geopolymer concrete and

24 Abstract:

25 In this study, the effect of fly ash characteristics, the content of the fly ash and mix proportion 26 of the Fly Ash-Based Geopolymer Concrete (FBGC) on the bond strength between the FBGC 27 and steel reinforcement were examined. Australian fly ashes from five different sources 28 (Eraring, Mt-Piper, Bayswater, Gladstone and Collie) were used in producing FBGC. A total 29 of 45 FBGC mixes with different fly ash content $\left(300,400\right.$ and $\left.500 \mathrm{~kg} / \mathrm{m}^{3}\right)$ and different proportions of alkaline activator were prepared. The use of different fly ashes and in different amounts showed significant differences in the bond strength between the FBGC and steel reinforcement. It was found that the fly ash characteristics including particle size distribution and the content of $\mathrm{SiO}_{2} \mathrm{Al}_{2} \mathrm{O}_{3}$ and $\mathrm{CaO}$ influenced the bond strength of the $\mathrm{FBGC}$ significantly. The results showed that the FBGC that was mixed with Gladstone (GL) fly ash exhibited the highest average bond strength between the FBGC and steel reinforcement (25 $\mathrm{MPa}$ ). While the FBGC that was mixed with Bayswater (BW) fly ash showed the lowest average bond strength between the FBGC and steel reinforcement (10 MPa). The results also indicated that the increase in the fly ash content in the FBGC significantly increased the bond strength between the FBGC and steel reinforcement. The bond strength of the FBGC responded differently to changes in the $\mathrm{Na}_{2} \mathrm{SiO}_{3} / \mathrm{NaOH}$ ratio in the alkaline activator corresponding to the use of different fly ash.

42 Keywords: Geopolymer concrete; Bond strength; Fly ash; steel reinforcement; Alkaline activator. 


\section{Introduction}

45 Geopolymer concrete is developing as an environmentally friendly alternative to Portland

46 Cement Concrete (PCC). The geopolymer concrete is synthesised by mixing a geopolymer

47 binder (aluminosilicate material and alkaline activator) with aggregate. In general, the geopolymer binder is prepared by mixing an aluminosilicate material (i.e. fly ash and blast furnace slag) with an alkaline activator, i.e. sodium hydroxide $(\mathrm{NaOH})$ and sodium silicate $\left(\mathrm{Na}_{2} \mathrm{SiO}_{3}\right)$. The chemical reaction (geopolymerization) between the aluminosilicate material and the alkaline activator forms a three-dimensional inorganic polymer with coherent and adhesive properties [1].

53

The use of fly ash (by-products of coal combustion in power stations) in producing geopolymer concrete is gaining more interest by many researchers across the world. This is because the fly ash is one of the cheapest aluminosilicate materials which is rich in silica ( $\mathrm{SiO}_{2} 40 \%-70 \%$ by weight) and alumina $\left(\mathrm{Al}_{2} \mathrm{O}_{3} 15 \%-30 \%\right.$ by weight $)[2,3]$. Moreover, the use of fly ash in the geopolymer concrete contributes in reducing the environmental impacts due to disposing fly ash in landfills [4]. However, fly ashes produced from different power stations have different characteristics because of using different fuel types (bituminous and

61 lignite coal) and different techniques in collecting the fly ashes making the fly ash a non-

62 standard material $[5,6]$. As such, fly ashes from different sources will have different extent of geopolymerization with alkaline activators that affects the properties of the Fly Ash-Based Geopolymer Concrete (FBGC). This is due to the differences in the fly ash characteristics in terms of particle size distribution, amorphous $\mathrm{SiO}_{2}$ and $\mathrm{Al}_{2} \mathrm{O}_{3}$ content and $\mathrm{CaO}$ content [710]. Consequently, using fly ash from different sources in producing FBGC has different

67 performance in structural members. Thus, understanding the factors that affect the 
performance of the FBGC with steel reinforcement is necessary to promote the use of FBGC as a potential alternative to the PCC.

Reinforced concrete members generally rely on the interfacial bond between the reinforcing bars and the surrounding concrete $[11,12]$. Transferring the forces between a steel rebar and the surrounding concrete depends on chemical adhesion, friction and the mechanical interlocking between steel ribs and the concrete [11]. The performance of the concrete to resist stresses transferred from the reinforcing bars is dominated by the compressive and the tensile strengths of the surrounding concrete [11].

The bond strength between the FBGC and steel reinforcement has been investigated in different studies [13-18]. The effects of the bar size of steel reinforcement, the embedded length of the steel bar, the thickness of the concrete cover and curing conditions of FBGC on the bond strength between the FBGC and steel reinforcement were investigated by several studies. However, the existing studies did not investigate the effect of using different fly ash sources (different characteristics) and different mix proportion on the bond strength between the FBGC and steel reinforcement. The present study examines the effect of different fly ash sources (five different Australian fly ash sources) and different mix proportion of the FBGC (three different fly ash contents and three different weight ratios of $\mathrm{Na}_{2} \mathrm{SiO}_{3} / \mathrm{NaOH}$ ) on the bond strength between the FBGC and steel reinforcement.

88

89 2. Experimental work

$90 \quad 2.1$ Materials

\subsubsection{Fly ash}

92 Fly ashes (Type F) from Eraring (ER), Mt Piper (MP), Bayswater (BW), Gladstone (GL), and

93 Collie (CL) power stations were used in this study. The X-Ray Fluorescent (XRF) was 
carried out on samples of fly ash in the laboratories of the School of Earth \& Environmental Sciences, University of Wollongong, Australia. The particle size distribution analysis for the fly ash samples were carried out using laser diffraction particle size analyser. The results of the XRD and XRF analysis of the fly ash are summarised in Table 1, respectively. The particle size distribution of the fly ash samples is illustrated in Figure 1.

99

100 The analysis of the XRF showed that all fly ash samples were Type F based on the definition of ASTM-C618 (2015). The amount of $\mathrm{SiO}_{2}, \mathrm{Al}_{2} \mathrm{O}$ and $\mathrm{Fe}_{2} \mathrm{O}_{3}$ content for all fly ashes were higher than $70 \%$. The $\mathrm{CaO}$ content in all fly ash samples were less than $8 \%$. The percentages of the Loss on Ignition (LOI) for the unburned particles in all fly ashes ranged from $0.7 \%$ to 1.7\%. The median particle size (d50) of the fly ashes Eraring, Mt Piper, Bayswater, Gladstone, and Collie were 24.8, 20.5, 17.0, 3.5 and $9.0 \mu \mathrm{m}$, respectively.

106

107

\subsubsection{Alkaline activator}

108

The alkaline activator utilised in this study was composed of different proportions of $\mathrm{NaOH}$ and $\mathrm{Na}_{2} \mathrm{SiO}_{3}$. The $\mathrm{NaOH}$ solution was prepared by diluting caustic soda, which contained about $98 \%$ by weight $\mathrm{Na}_{2} \mathrm{O}$ in water. The $\mathrm{Na}_{2} \mathrm{SiO}_{3}$ composed of $29.4 \% \mathrm{SiO}_{2}, 14.7 \% \mathrm{Na}_{2} \mathrm{O}$ and $55.9 \%$ water by wieght.

113 The optimum concentration of the $\mathrm{NaOH}$ and the weight ratio of the alkaline activator to the

114 fly ash content (AL/FA) for each fly ash source were determined by conducting sets of 115 geopolymer trial mixes. For this aim, five sets of fly ash-based geopolymer mortar (FGBM) 116 mixes were prepared and tested for compressive strength. The details of the mix proportion of 117 the geopolymer mortar are summarised in Table 2. The weight ratio of fly ash to sand was 118 fixed at 1:2.75 according to [19]. The results of the compressive strength of the FBGM show 
119 that the optimum concentration of $\mathrm{NaOH}$ and the optimum AL/FA for ER, MP and BW fly

120 ashes were 16 mole/ $\mathrm{L}$ and 0.6 , respectively. While the optimum $\mathrm{NaOH}$ concentration and the

121 optimum AL/FA for GL and CL fly ashes were 12 mole/L and 0.5 , respectively. The results

122 showed that fly ash with a high percentage of fine particles and amorphous components $\left(\mathrm{SiO}_{2}\right.$

123 and $\mathrm{Al}_{2} \mathrm{O}_{3}$ ) such as $\mathrm{GL}$ and $\mathrm{CL}$ fly ashes required a low dosage of alkaline activator to

124 achieve the highest compressive strength. While ER, MP and BW fly ashes required a high concentration of the $\mathrm{NaOH}$ and AL/FA to achieve the highest compressive strength.

The effect of using an alkaline activator with different content of $\mathrm{Na}_{2} \mathrm{SiO}_{3}$ and $\mathrm{NaOH}$ on the bond strength between the FBGC and steel reinforcement was investigated. For this aim, the $\mathrm{Na}_{2} \mathrm{SiO}_{3}$ and the $\mathrm{NaOH}$ were blended into three $\mathrm{Na}_{2} \mathrm{SiO}_{3} / \mathrm{NaOH}$ weight ratios which are 1.5 , 2.0 and 2.5. These ranges of the $\mathrm{Na}_{2} \mathrm{SiO}_{3} / \mathrm{NaOH}$ ratios were used previously in several studies [20-22].

\subsubsection{Aggregate}

134 Coarse aggregate with a maximum size of $14 \mathrm{~mm}$ and specific gravity of 2.6 was utilised in

135 the geopolymer concrete mixes. The coarse aggregate used in this study was crushed basalt 136 aggregate with water absorption of $0.77 \%$. Fine aggregate $(<4.75 \mathrm{~mm})$ with a specific 137 gravity of 2.5 and a fineness modulus of 3.2 was also used in the geopolymer concrete mixes.

138 Both coarse and fine aggregates were used in the saturated surface-dry (SSD) condition.

\subsubsection{Steel bar}

141 To investigate the bond behaviour between the geopolymer concrete and steel reinforcement,

142 deformed steel bars with a nominal diameter of $16 \mathrm{~mm}$ were used in this study. The nominal 143 tensile strength of the deformed steel bar was $500 \mathrm{MPa}$. 
145 In this study, mixes of the FBGC were prepared by mixing fly ashes (Type F), alkaline

146 activators (mix of $\mathrm{NaOH}$ and $\mathrm{Na}_{2} \mathrm{SiO}_{3}$ ), water, fine aggregate and coarse aggregate in

147 different mix proportions. These mixes were divided into five groups according to the source

148 of fly ash, which are ER, MP, BW, GL and CL. Nine mixes of FBGC were prepared for each

149 group. Fly ash in the FBGC groups was blended with $\mathrm{Na}_{2} \mathrm{SiO}_{3} / \mathrm{NaOH}$ ratios of $1.5,2.0$, and

1502.5 ; the mixes of the FBGC in each group were mixed with 300,400 , and $500 \mathrm{~kg} / \mathrm{m}^{3}$ of fly

151 ash. The maximum reduction in the total volume of aggregate due to increasing the fly ash

152 content from 300 to $500 \mathrm{~kg} / \mathrm{m}^{3}$ was $24 \%$. Water was used to control the slump of the FBGC.

153 The fine and coarse aggregates were selected based on the method prescribed in ACI-211.1

154 [23] for normal concrete. The details of the geopolymer concrete mixes are listed in Table 3.

155 The fly ash and aggregate were dry mixed for three minutes, then the pre-mixed alkaline

156 activator was added and blended for another four minutes. Water was added to the 157 geopolymer concrete mixes to maintain a slump between 80 to $100 \mathrm{~mm}$, after which the 158 mixes were poured into moulds and compacted by a vibrating table. These specimens were 159 kept at ambient temperature for 24 hours as proposed by Vora and Dave [24], then cured in 160 an oven at $70^{\circ} \mathrm{C}$ for 24 hours as recommended by Gunasekara et al. [25] and Soutsos et al.

161 [26]. During heat curing, the specimens were covered with plastic sheets to prevent loss of moisture. The specimens were then taken out of the moulds and kept at room temperature before being tested.

165 The mixes of the FBGC were identified according to the fly ash source, fly ash content and $166 \mathrm{Na}_{2} \mathrm{SiO}_{3} / \mathrm{NaOH}$ ratio. The sources of fly ash were labelled ER, MP, BW, GL, and CL, which 167 denotes the Eraring, Mt-Piper, Bayswater, Gladstone and Collie, respectively; while the amount of fly ash was denoted by values of 300,400 and $500 \mathrm{~kg} / \mathrm{m}^{3}$. The ratio of 
$169 \mathrm{Na}_{2} \mathrm{SiO}_{3} / \mathrm{NaOH}$ was expressed by the letter $\mathrm{R}$, followed by the ratios $(1.5,2.0$, and 2.5). For 170 example, Mix ER500R2.5 refers to geopolymer concrete that was mixed with fly ash from

171 Eraring power station, with $500 \mathrm{~kg} / \mathrm{m}^{3}$ fly ash and $\mathrm{Na}_{2} \mathrm{SiO}_{3} / \mathrm{NaOH}$ in the ratio of 2.5.

172

$173 \quad 2.3$ Test procedure

\section{$174 \quad$ 2.3.1 Bond strength test}

175 Direct pull-out tests were carried out according to European Standard EN-10080 [27] to

176 determine the bond strength between FBGC and steel reinforcement. The bond test was

177 carried out on cubic specimens $160 \mathrm{~mm}$ sides in accordance to the EN-10080 [22]. A $16 \mathrm{~mm}$

178 diameter deformed steel bar was embedded in the middle of the cubic specimens to a length

179 of five times its diameter, as recommended by EN-10080 [22]; details of the test specimens

180 are shown in Figure 2. Three specimens from each mix were tested at the age of 7 days. In

181 total, 45 mixes of the FBGC were examined for the bond strength test. These bond tests were

182 carried out in the Highbay laboratory, School of Civil, Mining and Environmental

183 Engineering, University of Wollongong, Australia.

184

185 The type of failure was identified, and the bond stress-slip relationship was recorded by a

186 computer mounted onto the testing machine (Instron 8033 testing machine). According to

187 EN-10080 [22], the bond strength was calculated using the following formula:

$$
\tau=\frac{F_{U}}{5 d^{2} \pi}
$$

where $\tau$ is the bond strength, $F_{U}$ is the ultimate pull out force, and $d$ is the bar diameter. 
191 The $100 \mathrm{~mm}$ diameter by $200 \mathrm{~mm}$ high cylinders were tested for compressive strength of

192 concrete according to AS1012.9 [28] at the age of 7 days. The average compressive strength

193 of three specimens was reported for each mix. The compressive strength and was obtained

194 using a W\&T Avery Testing Machine with a loading capacity of $1800 \mathrm{kN}$. The test was

195 carried out in the Highbay laboratory, School of Civil, Mining and Environmental

196 Engineering, University of Wollongong, Australia.

197

198

\subsubsection{Scanning Electron Microscopy (SEM) analysis}

199 The Scanning Electron Microscope (SEM) was performed on the crushed FBGC. Neoscope

200 SEM-JSM 6000 at the Nanotechnology laboratory at the School of Mechanical, Materials,

201 Mechatronic and Biomedical Engineering, University of Wollongong, Australia was used for the SEM analysis. The SEM was conducted to investigate the effect of different fly ashes on the microstructure of the FBGC. Also, the SEM was used to examine the effect of increasing

204 the fly ash content in the FBGC on the microstructure.

205

206 3. Results and discussion

207

3.1 Bond strength

208 The failure mode of pull-out specimens of the FBGC and the effects of test parameters (fly

209 ash type, fly ash content and $\mathrm{Na}_{2} \mathrm{SiO}_{3} / \mathrm{NaOH}$ ratio) on the bond strength were evaluated. The

210 results of the pull-out test of the FBGC are summarised in Table 3. 
213 All FBGC pull-out specimens failed when the concrete cover split along the steel bar

214 referring to the brittle nature of the FBGC as shown in Figure 3. The splitting failure occurs

215 when the forces induced between the steel ribs and the surrounding concrete exceeds the maximum tensile strength of the FBGC. The splitting failure of the FBGC in the pull-out test was also reported by Sofi et al. [13], Sarker [14] and Topark-Ngarm et al. [17].

It was observed that the mode of splitting failure was significantly influenced by the fly ash content in FBGC mixes. Typically, the propagation of cracks in the FBGC with high fly ash content $\left(500 \mathrm{~kg} / \mathrm{m}^{3}\right)$ occurred suddenly through the geopolymer paste and resulted in splitting the specimens, as shown in Figure 3a. On the other hand, the propagation of cracks in the FBGC with low fly ash content $\left(300 \mathrm{~kg} / \mathrm{m}^{3}\right)$ took a time before splitting the FBGC, as shown in Figure 3b. The effect of the fly ash content in the FBGC on the failure mode may be attributed to the variance in the total volume of the aggregate that was replaced by the fly ash in the FBGC mixes. Increasing the fly ash content in the FBGC from 300 to $500 \mathrm{~kg} / \mathrm{m}^{3}$ reduced the total volume of aggregate by about $24 \%$. The aggregate, especially the coarse aggregate, works on delaying the crack propagation that initially occurred at the interfacial transition zone (ITZ) between the aggregate and the geopolymer paste [11].

The mode of the splitting failure of the FBGC in the pull-out test was influenced by the compressive strength of the FBGC. It was found that increasing the fly ash content in the FBGC promoted the compressive strength of the produced FBGC (see Table 3). The increase

234 in the compressive strength of the concrete correlates to the increase of the brittleness of the concrete [11]. As a result, increasing the fly ash content in the FBGC results in increasing the 
236 brittleness of the FBGC, which in turn affects the mode of failure of the FBGC during the

237 pull-out test.

238

239

\subsubsection{Bond strength of the FBGC}

\subsubsection{Effect of fly ash type on the bond strength of the FBGC}

241 The effect of using different fly ash sources on the bond strength between the FBGC and steel reinforcement is shown in Figure 4. The bond strength between the FBGC and steel reinforcement was significantly influenced by the source of fly ash. The FBGC that was mixed with GL fly ash exhibited the highest bond strength between the FBGC and steel reinforcement where the average bond strength was $25 \mathrm{MPa}$. On the other hand, The FBGC that was mixed with BW fly ash showed the lowest bond strength between the FBGC and steel reinforcement where the average bond strength was $10.3 \mathrm{MPa}$. The high average bond strength of the FBGC that were mixed with GL fly ash may be attributed to the lowest median particle size, the high content of amorphous component $\left(\mathrm{SiO}_{2}\right.$ and $\left.\mathrm{Al}_{2} \mathrm{O}_{3}\right)$ and the highest $\mathrm{CaO}$ content. The different characteristics of different fly ashes lead to different extent of geopolymerization between the fly ash and the alkaline activator, which in turn influences properties of the produced FBGC.

The different extent of the geopolymerization affects the microstructure of the FBGC that consequently affects the bond with a steel bar. This is true when comparing the microstructure of the FBGC that were mixed with different fly ashes. Figure 5 a-e show the SEM images of the microstructure of Mixes ER500R2.5, MP500R2.5, BW500R2.5, GL500R1.5 and CL500R1.5 that achieved the highest bond strength of the FBGC that were mixed with ER, MP, BW, GL and CL fly ashes, respectively. The results show that using

260 different fly ashes exhibited different microstructure of the FBGC. The microstructures of 

contained a higher amount of unreacted particles, voids and cracks between the aggregate particles than those observed in Mixes GL500R1.5, CL500R1.5 (Figure $5 \mathrm{~d}$ and e). The weakest microstructure was observed in FBGC that was mixed with BW fly ash (Figure $5 \mathrm{c}$ ) where the highest amount of unreacted fly ash particles, a large amount of irregular voids and cracks were found, which is consistent with the lower average bond strength.

The presence of unreacted particles, voids and crakes in the microstructure of the FBGC represent weak points that failure may start and/or pass through it [29]. Because of this, the bond performance between the FBGC and steel reinforcement declines significantly. These results suggested that the bond strength is essentially dependent on the fly ash characteristics.

\subsubsection{Effect of fly ash content on the bond strength of the FBGC}

274 The effect of the fly ash content in the FBGC on the bond strength between the FBGC and

275 the steel reinforcement is illustrated in Figure 4. An increase in the amount of fly ash from 276300 to $500 \mathrm{~kg} / \mathrm{m}^{3}$ in the FBGC mixes increased the bond between the FBGC and steel

277 reinforcement. The maximum increase in the bond strength of the FBGC that were mixed with ER, MP, BW, GL and CL fly ashes were 36\%, 16\%, 29\%, 26\% and 29\%, respectively.

279 This improvement in the bond between the FBGC and the steel reinforcement may be

280 attributed to the improvement in the microstructure of the FBGC that is associated with increasing the fly ash content in the FBGC as shown in Figure 6 a-d. Using a lower content of fly ash $\left(300 \mathrm{~kg} / \mathrm{m}^{3}\right)$ in the FBGC resulted in forming a non-homogeneous and loosely

283 structured matrix. Unreacted particles and large irregular voids are likely to be found, as

284 shown in Figure 6 a and c. As discussed above, the presence of unreacted fly ash particles, 
voids, and crakes in the microstructure of the FBGC reduces the bond between the FBGC and steel bar.

The poor microstructure of the FBGC that used the lower content of fly ash $\left(300 \mathrm{~kg} / \mathrm{m}^{3}\right)$ may be attributed to the poor consolidation of FBGC components. Fly ash particles facilitate flow between the aggregate particles owing to the spherical shape and smooth surface of the fly ash particles [8]. Thus, lowering the fly ash content $\left(300 \mathrm{~kg} / \mathrm{m}^{3}\right)$ reduces the ability of the FBGC components to consolidate properly around the steel bar which in turn leads to less integration between the FBGC and the steel bar.

The use of high fly ash content $\left(500 \mathrm{~kg} / \mathrm{m}^{3}\right)$ in the FBGC resulted in a dense and compacted microstructure, as shown in Figure $6 \mathrm{~b}$ and d. This improvement in the microstructure of the FBGC that was mixed with high fly ash content $\left(500 \mathrm{~kg} / \mathrm{m}^{3}\right)$ may be attributed to the increase in the packing density (the ratio of volume fraction occupied by the solids to the volume of the surrounding container) of the FBGC matrix. Increasing the fly ash content increases the volume of the fine fraction particles in the FBGC matrix which in turn fill the voids between the aggregate particles and the steel bar. As a result, increasing the fly ash content in the FBGC improves the microstructure of the FBGC which in turn improves the bond between the FBGC and the steel reinforcement.

\subsubsection{Effect of $\mathrm{Na}_{2} \mathrm{SiO}_{3} / \mathrm{NaOH}$ ratio on the bond strength of the FBGC}

The increase of the $\mathrm{Na}_{2} \mathrm{SiO}_{3} / \mathrm{NaOH}$ ratio in the alkaline activator from 1.5 to 2.5 in the FBGC that were mixed with ER, MP and BW fly ashes fly ashes increased the bond strength

308 between the FBGC and steel reinforcement, as shown in Figure 4. The increase in the bond strength between the FBGC and steel reinforcement reached 36\%, 29\%, and 16\% for FBGC 
310 that were mixed with ER, MP and BW fly ashes, respectively, which is in line with the

311 findings of Sarker [14]. However, Figure 4 shows that an increase in the $\mathrm{Na}_{2} \mathrm{SiO}_{3} / \mathrm{NaOH}$ ratio

312 from 1.5 to 2.5 caused a considerable reduction in the bond between FBGC and steel

313 reinforcement by $19 \%$ and $13 \%$ for the FBGC that were mixed with GL and CL fly ashes,

314 respectively. As a result, increasing the $\mathrm{Na}_{2} \mathrm{SiO}_{3} / \mathrm{NaOH}$ ratio in the FBGC does not show a

315 clear effect on the bond strength of the FBGC due to using different fly ashes that required

316 different optimum $\mathrm{Na}_{2} \mathrm{SiO}_{3} / \mathrm{NaOH}$ ratios to achieve the highest bond strength of the FBGC.

318 The alkaline activator components $\left(\mathrm{Na}_{2} \mathrm{SiO}_{3}\right.$ and $\left.\mathrm{NaOH}\right)$ are mainly composed of the 319 molecules including $\mathrm{SiO}_{2}$ and $\mathrm{Na}_{2} \mathrm{O}$ in different ratios. In order to understand the effect of the $320 \mathrm{Na}_{2} \mathrm{SiO}_{3} / \mathrm{NaOH}$ ratio on the bond strength of the FBGC, relationships between bond strength 321 of the FBGC and the liquid $\mathrm{SiO}_{2}$ as well as with $\mathrm{Na}_{2} \mathrm{O}$ in the alkaline activator were performed. The relationship between the content of the liquid $\mathrm{SiO}_{2}$ in the $\mathrm{Na}_{2} \mathrm{SiO}_{3}$, which represents $29.4 \%$ by weight, and the bond strength of the FBGC were conducted as shown in

324 Figure 7. The results show that the bond strength of the FBGC increased significantly with 325 increasing the amount of the liquid $\mathrm{SiO}_{2}$ in the $\mathrm{FGBC}$. The increase of the liquid $\mathrm{SiO}_{2}$ content results in increasing the reactive silica in geopolymer matrix forming a silicon-rich gel which has compacted and higher mechanical properties [30]. As a result, the higher bond strength of the geopolymer is associated with the higher liquid $\mathrm{SiO}_{2}$ in the $\mathrm{FBGC}$ matrix.

329 In addition, the effect of the total $\mathrm{Na}_{2} \mathrm{O}$ content in alkaline activator components (14\% by 330 weight of $\mathrm{Na}_{2} \mathrm{SiO}_{3}$ and $28 \%-35 \%$ by weight of $\mathrm{NaOH}$ ) on the bond strength between the

331 FBGC and steel reinforcement was evaluated. Figure 8 shows the relationship between the 332 total $\mathrm{Na}_{2} \mathrm{O}$ of the alkaline activator on the bond strength of the FBGC. The results show that 333 increasing the $\mathrm{Na}_{2} \mathrm{O}$ in the alkaline activator reduced the bond strength of the FBGC, 334 irrespective of the type and content of the fly ash. In fact, the $\mathrm{Na}_{2} \mathrm{O}$ content controls the 
335 extent of leaching the fly ash components $\left(\mathrm{SiO}_{2}\right.$ and $\left.\mathrm{Al}_{2} \mathrm{O}_{3}\right)$ in the geopolymer mix while the 336 fly ash is being geopolymerised [31, 32]. Consequently, the $\mathrm{Na}_{2} \mathrm{O}$ content affects the

337 cohesion of geopolymer structure, which in turn affects the bond strength of the FBGC with 338 steel reinforcement.

3.1.2.4 Effect of the water content in the FBGC on the bond strength with steel reinforcement

341 The increase of water content in the normal concrete reduces the bond strength with steel

342 reinforcement; increasing the water content in concrete increases the bleed of water that

343 occurs due to concrete consolidation resulting in forming open pores between concrete and 344 steel [33]. In the FBGC, the alkaline activator is the main source of water $(55.9 \%$ by weight 345 of the $\mathrm{Na}_{2} \mathrm{SiO}_{3}$ and about $60 \%$ by weight of the $\mathrm{NaOH}$ ) in the mix. Also, water is added to 346 the geopolymer mix to control the slump of the geopolymer concrete mix. In this study, the 347 effect of added water on the bond strength of the FBGC was evaluated.

349 The effect of the added water on the bond strength of the FBGC is illustrated in Figure 9. For all FBGC specimens, increasing the added water in the FBGC resulted in a significant decrease in the bond strength. The amount of reduction in the bond strength between the

352 FBGC and steel reinforcement was significantly influenced by the fly ash source. The 353 maximum reduction was observed in the FBGC that was mixed with CL fly ash where the reduction in the bond strength between the FBGC and steel reinforcement reached $38 \%$ due increasing the amount of the added water from 7 to $15 \mathrm{~kg} / \mathrm{m}^{3}$. While the maximum reduction in the bond strength of the FBGC that was mixed with ER fly ash was $25 \%$ when the added water increased from 5 to $14 \mathrm{~kg} / \mathrm{m}^{3}$. 
359 This reduction in the bond strength of the FBGC due to increasing the amount of the added

360 water in the mixes may be attributed to evaporation of the water from the concrete, when

361 curing at high temperature, leaving pores and cavities within geopolymer matrix. In addition,

362 the added water may affect the alkalinity ( $\mathrm{pH}$ value) of the geopolymer matrix that could lead

363 to reducing the rate of the geopolymerization between fly ash and alkaline activator.

\subsection{Compressive strength}

The results of the compressive strength of the FBGC are summarised in Table 3. The compressive strength of the FBGC at the age of 7 days was in the range between $16 \mathrm{MPa}$ to $64 \mathrm{MPa}$. The results show a substantial difference in the compressive strength of the FBGC due to effects of the tested parameters including the type and content of fly ashes, the dosage of the alkaline activator in terms of liquid $\mathrm{SiO}_{2}$ and $\mathrm{Na}_{2} \mathrm{O}$ and the added water. The results showed that the tested parameters influenced the compressive strength of the FBGC similarly to that was observed in the bond strength between FBGC and steel reinforcement. The compressive strength of the FBGC that was mixed with GL fly ash was in the range of 34.4 $\mathrm{MPa}$ to $64 \mathrm{MPa}$, whereas the compressive strength of FBGC that was mixed with BW fly ash was from $16 \mathrm{MPa}$ to $23.2 \mathrm{MPa}$.

\subsection{Relationship between the bond strength and the compressive strength of the FBGC}

378 The bond strength between the FBGC and the steel reinforcement and the corresponding 379 compressive strength are plotted in Figure 10. The results show that the bond strength between the FBGC and the steel reinforcement increases significantly with increasing the corresponding compressive strength. Different models were proposed to estimate the bond strength between the PCC and the steel reinforcement in terms of the compressive strength. A comparison was carried out with the models proposed for the bond strength of the PCC by 
384 Orangun et al. [34], Hadi [35] and CEB-FIP [36] in Eqs 2, 3 and 4, respectively. These 385 models were plotted along with the experimental results of the bond strength between the 386 FBGC and steel reinforcement in this study as shown in Figure 10. It can be seen that the 387 experimental results of the bond strength between the FBGC and the steel reinforcement in 388 this study were generally higher than those calculated by Eqs 2, 3 and 4. However, models of

389 Orangun et al. [34] and CEB-FIP [36] in Eqs 2 and 3, respectively gave comparable values of 390 the bond strength at a range of compressive strength lower than $25 \mathrm{MPa}$. While, the bond 391 strength values that were estimated by the model of Hadi [35] in Eq 4 were $37 \%$ to $66 \%$ 392 lower than the experimental results in this study. These results imply that the bond strength of 393 the FBGC is significantly higher than the bond strength of the PCC in the range of 394 compressive strength higher than $25 \mathrm{MPa}$.

395

$$
\begin{aligned}
\tau & =2.18{f_{c}^{\prime}}^{0.5} \\
\tau & =1.33{f_{c}^{\prime}}^{0.5} \\
\tau & =2.51{f_{c}^{\prime}}^{0.5}
\end{aligned}
$$

396 where $\tau$ is the bond strength (MPa), $f_{c}^{\prime}$ is the compressive strength of the FBGC (MPa).

398 As a result, a model was derived based on the results of the bond strength of 45 FBGC mixes.

399 For this aim, power regression law was used in fitting the relevant best fit line. The model 400 parameters (intercept and power values) were determined using logarithm method [37]. As a 401 result, a model with a correlation factor $\left(\mathrm{R}^{2}\right)$ of 0.84 was developed as shown in Eq 5.

$$
\tau=1.35 f_{c}^{\prime 0.75}
$$

402 The $\pm 95 \%$ confidence intervals were calculated by using Eq 6 while $\pm 95 \%$ prediction 403 intervals were determined by using Eq 7 [38]. The confidence and prediction intervals at a 
probability level of $\pm 95 \%$ for the power regression line were calculated and plotted along with the relevant best fit line.

406

$$
\begin{aligned}
& \tau_{95 \% \text { confidence }}=\tau_{\text {predicted }} \pm t_{0.05}\left(\sqrt{\frac{\sum\left(\tau-\tau_{\text {predicted }}\right)^{2}}{i-2}} * \sqrt{\frac{1}{i}+\frac{\left(f_{c}^{\prime}-f_{\text {cave }}^{\prime}\right)^{2}}{s s_{x}}}\right) \\
& \tau_{95 \% \text { prediction }}=\tau_{\text {predicted }} \pm t_{0.05}\left(\sqrt{1+\frac{\sum\left(\tau-\tau_{\text {predicted }}\right)^{2}}{i-2}} * \sqrt{1+\frac{1}{i}+\frac{\left(f_{c}^{\prime}-f_{\text {cave }}^{\prime}\right)^{2}}{s s_{x}}}\right)
\end{aligned}
$$

where $\tau_{95 \% \text { confidence }}$ is the $95 \%$ confidence interval value of the predicted bond strength, $\tau_{95 \%}$ prediction is the $95 \%$ prediction interval of the predicted bond strength, $\tau_{\text {predicted }}$ is the predicted bond strength using the developed model in $\mathrm{Eq} 5, f_{c \text { ave }}^{\prime}$ is the average of the compressive strength. The $t_{0.05}$ is the $t$-test critical value for $95 \%$ interval, and $s s_{x}$ is the sum of the squares of the standard error of input values.

414 The model in Eq 5 was evaluated using the available experimental data from studies were conducted on the bond strength of the FBGC by Sofi et al. [13] Topark-Ngarm et al. [17] and Dahou et al. [18]. The data were plotted along with the results of the bond strength between the FBGC and the steel reinforcement of this study as shown in Figure 10. It can be seen that the experimental data of Sofi et al. [13] and Topark-Ngarm et al. [17] were significantly lower than that estimated by developed model in Eq 5. This is because of the low curing temperature $\left(<60^{\circ} \mathrm{C}\right)$ that was used by Sofi et al. [13] and Topark-Ngarm et al. [17] in their experimental which in turns affecting the developing of the bond strength between the FBGC and steel reinforcement bar. In contrast, the experimental data of Dahou et al. [18] shows a good consistency with the model in Eq 5 where the data were between the \pm 95 prediction 424 intervals as shown in Figure 10. 


\section{Conclusion}

427 This study investigated the effects that the fly ash characteristics, amount of fly ash and different $\mathrm{Na}_{2} \mathrm{SiO}_{3} / \mathrm{NaOH}$ had on the bond between FBGC and steel reinforcement. The following conclusions can be drawn as based on the analysis of the results:

1. The bond strength between FBGC and steel reinforcement was from 7.5 to $30 \mathrm{MPa}$, and the source of fly ash affects the strength of the bond between the FBGC and the steel reinforcement quite considerably. The fly ash characteristics including particle size distribution, the content of the amorphous components $\left(\mathrm{SiO}_{2}\right.$ and $\left.\mathrm{Al}_{2} \mathrm{O}_{3}\right)$ and the $\mathrm{CaO}$ have a significant effect on the bond strength of the FBGC. The FBGC that was mixed with GL fly ash exhibited the highest average bond strength between the FBGC and steel

2. An increase in the amount of ash content from 300 to $500 \mathrm{~kg} / \mathrm{m}^{3}$ increased the brittleness of the FBGC that affects the mode of failure of the FBGC due to pull-out of the steel bar.

3. An increase in the amount of ash content from 300 to $500 \mathrm{~kg} / \mathrm{m}^{3}$ increased the bond between FBGC and steel reinforcement in the range between $16 \%$ to $36 \%$.

4. The strength of the bond between FBGC and steel reinforcement differed according to the increase in the $\mathrm{Na}_{2} \mathrm{SiO}_{3} / \mathrm{NaOH}$ ratio in the alkaline activator. An increase in the $\mathrm{Na}_{2} \mathrm{SiO}_{3} / \mathrm{NaOH}$ ratio in the FBGC that were mixed with GL and CL fly ashes reduced the strength of the bond between FBGC and steel reinforcement by $13 \%$ to $19 \%$, respectively. Increasing the $\mathrm{Na}_{2} \mathrm{SiO}_{3} / \mathrm{NaOH}$ ratio in the alkaline activators of the FBGC that were mixed with ER, MP, and BW fly ashes increased the strength of the bond between the FBGC and steel reinforcement up to $36 \%$. 
449 5. The bond strength of the FBGC increased with increasing the $\mathrm{SiO}_{2}$ used in the alkaline 450 activator. While it decreases significantly with increasing the total content of the $\mathrm{Na}_{2} \mathrm{O}$ in 451 the $\mathrm{NaOH}$ and the $\mathrm{Na}_{2} \mathrm{SiO}_{3}$.

452 6. The increase of the amount of added water in the FBGC reduced the bond strength 453 between the FBGC and steel reinforcement.

\section{Acknowledgements}

456 The authors would like to thank the University of Wollongong, Australia for providing 457 technical support and facilities to implement the experimental work of this study. The authors 458 acknowledge the Ash Development Association Australia for providing the fly ashes that 459 were used in this study. The first author would like to thank the Iraqi government for funding 460 his scholarship.

\section{References}

463 [1] Khale D, Chaudhary R. Mechanism of geopolymerization and factors influencing its 464 development: a review. Journal of Materials Science 2007; 42(3): 729-746.

465 [2] Rees CA, Provis JL, Lukey GC, Deventer JSJv. Attenuated total reflectance Fourier 466 transform infrared analysis of fly ash geopolymer gel ageing. American Chemical Society $467 \quad 2007 ; 23(15): 8170-8179$.

468 [3] Alvarez-Ayuso E, Querol X, Plana F, Alastuey A, Moreno N, Izquierdo M, Font O, 469 Moreno T, Diez S, Vazquez E, Barra M. Environmental, physical and structural 470 characterisation of geopolymer matrixes synthesised from coal (co-)combustion fly ashes. J $471 \quad$ Hazard Mater 2008; 154(1): 175-83. 
473 immobilisation by geopolymers based on mechanically activated fly ash. Ceramics $474 \quad$ International 2014; 40(6): 8479-8488.

475 [5] Brindle JH, McCarthy MJ. Chemical constraints on fly ash glass compositions. Energy \& 476 Fuels 2006; 20(6): 2580-2585.

477 [6] Kumar S, Kristály F, Mucsi G. Geopolymerisation behaviour of size fractioned fly ash. 478 Advanced Powder Technology 2015; 26(1): 24-30.

479 [7] Tennakoon C, Nazari A, Sanjayan JG, Sagoe-Crentsil K. Distribution of oxides in fly ash 480 controls strength evolution of geopolymers. Construction and Building Materials 2014; 71 : $481 \quad 72-82$.

482 [8] Rickard WDA, Williams R, Temuujin J, van Riessen A. Assessing the suitability of three 483 Australian fly ashes as an aluminosilicate source for geopolymers in high temperature 484 applications. Materials Science and Engineering: A 2011; 528(9): 3390-3397.

[9] Nikolić V, Komljenović M, Baščarević Z, Marjanović N, Miladinović Z, Petrović R. The 486 influence of fly ash characteristics and reaction conditions on strength and structure of 487 geopolymers. Construction and Building Materials 2015; 94: 361-370.

488 [10] Jaarsveld JGSv, Deventer JSJv, Lukey GC. The characterisation of source materials in 489 fly ash-based geopolymers. Materials Letters 2003; 57: 1272-1280.

490 [11] ACI-408R. Bond and Development of Straight Reinforcing Bars in Tension: ACI 491 Committee 408, USA, American Concrete Institute; 2003.

492 [12] ACI-318. Building Code Requirements for Structural Concrete (ACI 318-08) and 493 Commentary: ACI Committee 318, USA, Farmington Hills; 2011.

494 [13] Sofi M, van Deventer JSJ, Mendis PA, Lukey GC. Bond performance of reinforcing bars 495 in inorganic polymer concrete (IPC). Journal of Materials Science 2007; 42(9): 3107-3116. 
496 [14] Sarker PK. Bond strength of reinforcing steel embedded in fly ash-based geopolymer 497 concrete. Materials and Structures 2010; 44(5): 1021-1030.

498 [15] Ganesan N, Indira PV, Santhakumar A. Bond behaviour of reinforcing bars embedded in 499 steel fibre reinforced geopolymer concrete. Magazine of Concrete Research 2015; 67(1): 950016.

501 [16] Castel A, Foster SJ. Bond strength between blended slag and Class F fly ash geopolymer 502 concrete with steel reinforcement. Cement and Concrete Research 2015; 72: 48-53. [17] Topark-Ngarm P, Chindaprasirt P, Sata V. Setting time, strength, and bond of high-

504 calcium fly ash geopolymer concrete. Journal of Materials in Civil Engineering 2015; 27(7): 50504014198.

506 [18] Dahou Z, Castel A, Noushini A. Prediction of the steel-concrete bond strength from the 507 compressive strength of Portland cement and geopolymer concretes. Construction and 508 Building Materials 2016; 119: 329-342.

509 [19] ASTM-C109/C109M. Standard Test Method for Compressive Strength of Hydraulic 510 Cement Mortars (Using 2-in. or [50-mm] Cube Specimens): American Standard for Testing 511 Materials, United States, American Standard for Testing Materials; 2016.

512 [20] Olivia M, Nikraz H. Properties of fly ash geopolymer concrete designed by Taguchi 513 method. Materials \& Design 2012; 36: 191-198.

514 [21] Assi LN, Deaver E, ElBatanouny MK, Ziehl P. Investigation of early compressive 515 strength of fly ash-based geopolymer concrete. Construction and Building Materials 2016; 516 112: 807-815.

517 [22] Albitar M, Visintin P, Mohamed Ali MS, Drechsler M. Assessing behaviour of fresh and 518 hardened geopolymer concrete mixed with class-F fly ash. KSCE Journal of Civil 519 Engineering 2014; 19(5): 1445-1455. 
520 [23] ACI-211.1. Standard practice for selection proportions for normal, heavy-weight, and mass concrete: ACI manual of concrete practice, Part 1: Materials and general properties of concrete, Detroit, USA, American Concrete Institute; 2009.

523 [24] Vora PR, Dave UV. Parametric studies on compressive strength of geopolymer concrete.

524 Procedia Engineering 2013; 51: 210-219.

525 [25] Gunasekara MP, Law DW, Setunge S, Effect of composition of fly ash on compressive strength of fly, in: S. Smith (Ed.) 23rd Australasian Conference on the Mechanics of Structures and Materials, Southern Cross University, Byron Bay, NSW, 2014, pp. 113-118. [26] Soutsos M, Boyle AP, Vinai R, Hadjierakleous A, Barnett SJ. Factors influencing the compressive strength of fly ash based geopolymers. Construction and Building Materials $530 \quad 2016 ; 110: 355-368$.

[27] EN-10080. Bond test for ribbed and indented reinforcing steel - Pull-out test: European Standard, Brussels, Belgium, European Committee for Standardisation; 2005. [28] AS1012.9. Methods of testing concrete - Compressive strength tests - Concrete, mortar 534 and grout specimens: Australian Standard, Australia, Standards Australia International Ltd; 5352014.

536 [29] Zhu W, Sonebi M, Bartos PJM. Bond and interfacial properties of reinforcement in selfcompacting concrete. Materials and Structures 2004; 37: 442-448. [30] Ruiz-Santaquiteria C, Skibsted J, Fernández-Jiménez A, Palomo A. Alkaline 539 solution/binder ratio as a determining factor in the alkaline activation of aluminosilicates.

540 Cement and Concrete Research 2012; 42(9): 1242-1251.

541 [31] Bakri AMA, Kamarudin H, Bnhussain M, Rafiza AR, Zarina Y. Effect of $542 \mathrm{Na}_{2} \mathrm{SiO}_{3} / \mathrm{NaOH}$ ratios and $\mathrm{NaOH}$ molarities on compressive strength of fly-ash-based 543 geopolymer. ACI Materials Journal 2013; 109(5): 503-508. 
544 [32] Leong HY, Ong DEL, Sanjayan JG, Nazari A. The effect of different $\mathrm{Na}_{2} \mathrm{O}$ and $\mathrm{K}_{2} \mathrm{O}$

545 ratios of alkali activator on compressive strength of fly ash based geopolymer. Construction

546 and Building Materials 2016; 106: 500-511.

547 [33] Zhang HY, Kodur V, Qi SL, Wu B. Characterizing the bond strength of geopolymers at

548 ambient and elevated temperatures. Cement and Concrete Composites 2015; 58: 40-49.

549 [34] Orangun CO, Jirsa IO, J. E. Breen. A reevaluation of test data on development length 550 and splices. ACI Journal 1977; 74(3): 114-122.

551 [35] Hadi MNS. Bond of high strength concrete with high strength reinforcing steel. The 552 Open Civil Engineering Journal 2008; 2: 143-147.

553 [36] CEB-FIB. Fib model code for concrete structures 2010: Document Competence Center 554 Siegmar Kästl eK, Germany, 2010.

555 [37] Blaesser RJ, Couls LM, Lee CF, Zuniga JM, Malek MH. Comparing EMG amplitude 556 patterns of responses during dynamic exercise: Polynomial vs log-transformed regression.

557 Scandinavian Journal of Medicine \& Science in Sports 2015; 25(2): 159-165.

558 [38] Altman DG, Gardner MJ. Calculating confidence intervals for regression and 559 correlation. British medical journal 1988; 296 1238-1247. 
562 Table 1 Chemical composition of the fly ash samples.

563 Table 2 Details of the mix proportion of the geopolymer mortar.

564 Table 3 Details of mix proportion and results of the fly ash based geopolymer concrete. 
566 Figure 1 Particle size distribution of the fly ash samples.

567 Figure 2 Details of the bond strength test specimen.

568 Figure 3 Splitting failure of the pull-out test specimens; (a) Mix GL500R2.0, (b) Mix

569 GL300R2.0.

570 Figure 4 Variation of the bond strength with fly ash content of the FBGC mixes at different

$571 \quad \mathrm{Na}_{2} \mathrm{SiO}_{3} / \mathrm{NaOH}$ ratios.

572 Figure 5 SEM images of FBGC for Mixes; (a) ER500R2.5, (b) MP500R2.5, (c) BW500R2.5,

573 (d) GL500R1.5, (e) CL500R1.5.

574 Figure 6 The SEM images for Mixes; (a) ER300R2.5, (b) ER 500R2.5, (c) GL300R1.5 and 575 (d) GL500R1.5.

576 Figure 7 Relationship between the liquid $\mathrm{SiO}_{2}$ and the bond strength of the FBGC.

577 Figure 8 Relationship between the total $\mathrm{Na}_{2} \mathrm{O}$ and the bond strength of the FBGC.

578 Figure 9 Relationship between the added water and the bond strength of the FBGC.

579 Figure 10 Bond strength of the FBGC versus the compressive strength. 
Table 1 Chemical composition of the fly ash samples

\begin{tabular}{cccccc}
\hline Composition & $\begin{array}{c}\text { Eraring } \\
(\mathrm{ER})\end{array}$ & $\begin{array}{c}\text { Mt-Piper } \\
(\mathrm{MP})\end{array}$ & $\begin{array}{c}\text { Bayswater } \\
(\mathrm{BW})\end{array}$ & $\begin{array}{c}\text { Gladstone } \\
(\mathrm{GL})\end{array}$ & $\begin{array}{c}\text { Collie } \\
(\mathrm{CL})\end{array}$ \\
\hline $\mathrm{SiO}_{2}(\%)$ & 62.9 & 66.6 & 77.2 & 43.4 & 52.7 \\
$\mathrm{Al}_{2} \mathrm{O}_{3}(\%)$ & 25.8 & 25.9 & 15.2 & 26.2 & 33.4 \\
$\mathrm{CaO}(\%)$ & 2.3 & 0.4 & 0.6 & 5.4 & 1.0 \\
$\mathrm{Fe}_{2} \mathrm{O}_{3}(\%)$ & 3.1 & 0.9 & 2.5 & 17.4 & 9.0 \\
$\mathrm{~K}_{2} \mathrm{O}(\%)$ & 1.2 & 2.7 & 1.5 & 0.5 & 0.3 \\
$\mathrm{MgO}(\%)$ & 0.3 & 0.1 & 0.3 & 1.4 & 0.6 \\
$\mathrm{LOI}(\%)$ & 1.7 & 1.3 & 0.7 & 0.7 & 0.4 \\
\hline
\end{tabular}

581 
Table 2 Details of the mix proportion of the geopolymer mortar

\begin{tabular}{|c|c|c|c|c|}
\hline $\begin{array}{l}\text { Fly ash } \\
\text { Source }\end{array}$ & $\begin{array}{l}\text { Mix } \\
\text { No. }\end{array}$ & $\begin{array}{c}\mathrm{Na}_{2} \mathrm{SiO}_{3} / \\
\mathrm{NaOH} \\
\text { wt. ratio }\end{array}$ & $\begin{array}{l}\text { Alkaline } \\
\text { activator/ fly } \\
\text { ash wt. ratio }\end{array}$ & $\begin{array}{c}\text { Average } \\
\text { Compressive } \\
\text { Strength } \\
\text { (MPa) }\end{array}$ \\
\hline \multirow{9}{*}{$\begin{array}{l}\text { Eraring } \\
\text { (ER) }\end{array}$} & 1 & \multirow{9}{*}{2.0} & \multirow{3}{*}{0.5} & 14 \\
\hline & 2 & & & 16 \\
\hline & 3 & & & 21 \\
\hline & 4 & & \multirow{3}{*}{0.6} & 26 \\
\hline & 5 & & & 28 \\
\hline & 6 & & & 32 \\
\hline & 7 & & \multirow{3}{*}{0.7} & 13 \\
\hline & 8 & & & 18 \\
\hline & 9 & & & 24 \\
\hline \multirow{9}{*}{$\begin{array}{l}\text { Mt-Piper } \\
\text { (MP) }\end{array}$} & 1 & \multirow{9}{*}{2.0} & \multirow{3}{*}{0.5} & 15 \\
\hline & 2 & & & 20 \\
\hline & 3 & & & 25 \\
\hline & 4 & & \multirow{3}{*}{0.6} & 27 \\
\hline & 5 & & & 30 \\
\hline & 6 & & & 33 \\
\hline & 7 & & \multirow{3}{*}{0.7} & 19 \\
\hline & 8 & & & 23 \\
\hline & 9 & & & 29 \\
\hline \multirow{9}{*}{$\begin{array}{l}\text { Bayswater } \\
\text { (BW) }\end{array}$} & 1 & \multirow{9}{*}{2.0} & \multirow{3}{*}{0.5} & 12 \\
\hline & 2 & & & 18 \\
\hline & 3 & & & 16 \\
\hline & 4 & & \multirow{3}{*}{0.6} & 20 \\
\hline & 5 & & & 24 \\
\hline & 6 & & & 25 \\
\hline & 7 & & \multirow{3}{*}{0.7} & 14 \\
\hline & 8 & & & 17 \\
\hline & 9 & & & 21 \\
\hline \multirow{9}{*}{$\begin{array}{l}\text { Gladstone } \\
\text { (GL) }\end{array}$} & 1 & \multirow{9}{*}{2.0} & \multirow{3}{*}{0.5} & 62 \\
\hline & 2 & & & 58 \\
\hline & 3 & & & 56 \\
\hline & 4 & & \multirow{3}{*}{0.6} & 59 \\
\hline & 5 & & & 56 \\
\hline & 6 & & & 54 \\
\hline & 7 & & \multirow{3}{*}{0.7} & 45 \\
\hline & 8 & & & 43 \\
\hline & 9 & & & 38 \\
\hline \multirow{9}{*}{$\begin{array}{l}\text { Collie } \\
\text { (CL) }\end{array}$} & 1 & \multirow{9}{*}{2.0} & \multirow{3}{*}{0.5} & 46 \\
\hline & 2 & & & 43 \\
\hline & 3 & & & 40 \\
\hline & 4 & & \multirow{3}{*}{0.6} & 45 \\
\hline & 5 & & & 40 \\
\hline & 6 & & & 37 \\
\hline & 7 & & & 34 \\
\hline & 8 & & 0.7 & 31 \\
\hline & 9 & & & 30 \\
\hline
\end{tabular}


Table 3 Details of mix proportion and results of the fly ash based geopolymer concrete

\begin{tabular}{|c|c|c|c|c|c|c|c|c|c|}
\hline \multirow[b]{2}{*}{ Mix ID } & \multicolumn{2}{|c|}{ Fly ash } & \multirow{2}{*}{$\begin{array}{c}\begin{array}{c}\text { Alkaline } \\
\text { activator }\end{array} \\
\mathrm{Na}_{2} \mathrm{SiO}_{3} / \\
\mathrm{NaOH} \\
\text { wt. ratio }\end{array}$} & \multicolumn{2}{|c|}{ Aggregate } & \multirow{2}{*}{$\begin{array}{l}\text { Water } \\
\left(\mathrm{kg} / \mathrm{m}^{3}\right)\end{array}$} & \multirow{2}{*}{$\begin{array}{l}\text { Slump } \\
(\mathrm{mm})\end{array}$} & \multirow{2}{*}{$\begin{array}{l}\text { Average } \\
\text { Compressive } \\
\text { strength } \\
\text { (MPa) }\end{array}$} & \multirow{2}{*}{$\begin{array}{c}\text { Bond } \\
\text { strength } \\
(\mathrm{MPa})\end{array}$} \\
\hline & $\begin{array}{l}\text { Fly ash } \\
\text { type }\end{array}$ & $\begin{array}{l}\text { Fly ash } \\
\text { content } \\
\left(\mathrm{kg} / \mathrm{m}^{3}\right)\end{array}$ & & $\begin{array}{c}\text { Fine } \\
\left(\mathrm{kg} / \mathrm{m}^{3}\right)\end{array}$ & $\begin{array}{l}\text { Coarse } \\
\left(\mathrm{kg} / \mathrm{m}^{3}\right)\end{array}$ & & & & \\
\hline ER300R1.5 & \multirow{9}{*}{$\begin{array}{c}\text { Eraring } \\
\text { (ER) }\end{array}$} & \multirow{3}{*}{300} & 1.5 & 627 & 1333 & 14.5 & 92 & 17 & 9.5 \\
\hline ER300R2.0 & & & 2.0 & 628 & 1335 & 14.0 & 91 & 18 & 10.2 \\
\hline ER300R2.5 & & & 2.5 & 629 & 1336 & 14.0 & 91 & 21 & 10.4 \\
\hline ER400R1.5 & & & 1.5 & 554 & 1177 & 10.0 & 93 & 19 & 10.0 \\
\hline ER400R2.0 & & 400 & 2.0 & 555 & 1179 & 10.0 & 93 & 20 & 12.0 \\
\hline ER400R2.5 & & & 2.5 & 556 & 1181 & 9.5 & 92 & 22 & 14.0 \\
\hline ER500R1.5 & & \multirow{3}{*}{500} & 1.5 & 480 & 1020 & 6.5 & 94 & 22 & 10.4 \\
\hline ER500R2.0 & & & 2.0 & 482 & 1023 & 6.0 & 95 & 25 & 12.0 \\
\hline ER500R2.5 & & & 2.5 & 483 & 1026 & 5.7 & 94 & 26 & 14.0 \\
\hline MP300R1.5 & \multirow{9}{*}{$\begin{array}{l}\text { Mt-Piper } \\
\text { (MP) }\end{array}$} & \multirow{3}{*}{300} & 1.5 & 622 & 1321 & 12.7 & 93 & 19 & 8.6 \\
\hline MP300R2.0 & & & 2.0 & 623 & 1323 & 12.2 & 89 & 20 & 10.0 \\
\hline MP300R2.5 & & & 2.5 & 623 & 1324 & 12.0 & 91 & 20 & 11.7 \\
\hline MP400R1.5 & & & 1.5 & 546 & 1161 & 9.5 & 95 & 20 & 9.2 \\
\hline MP400R2.0 & & 400 & 2.0 & 548 & 1164 & 9.5 & 96 & 21 & 10.6 \\
\hline MP400R2.5 & & & 2.5 & 548 & 1165 & 9.2 & 94 & 22 & 12.6 \\
\hline MP500R1.5 & & \multirow{3}{*}{500} & 1.5 & 471 & 1000 & 7.0 & 95 & 21 & 13.7 \\
\hline MP500R2.0 & & & 2.0 & 475 & 1005 & 6.7 & 92 & 25 & 14.0 \\
\hline MP500R2.5 & & & 2.5 & 475 & 1005 & 6.7 & 93 & 26 & 15.0 \\
\hline BW300R1.5 & \multirow{9}{*}{$\begin{array}{c}\text { Bayswater } \\
\text { (BW) }\end{array}$} & \multirow{3}{*}{300} & 1.5 & 627 & 1333 & 16.5 & 88 & 16 & 7.5 \\
\hline BW300R2.0 & & & 2.0 & 628 & 1335 & 16.2 & 89 & 18 & 8.3 \\
\hline BW300R2.5 & & & 2.5 & 629 & 1336 & 16.2 & 88 & 19 & 9.8 \\
\hline BW400R1.5 & & \multirow{3}{*}{400} & 1.5 & 554 & 1177 & 13.7 & 90 & 18 & 9.5 \\
\hline BW400R2.0 & & & 2.0 & 555 & 1179 & 13.0 & 91 & 19 & 10.5 \\
\hline BW400R2.5 & & & 2.5 & 556 & 1181 & 13.0 & 91 & 20 & 11.2 \\
\hline BW500R1.5 & & \multirow{3}{*}{500} & 1.5 & 480 & 1020 & 10.0 & 93 & 21 & 10.5 \\
\hline BW500R 2.0 & & & 2.0 & 482 & 1023 & 9.5 & 92 & 21 & 11.8 \\
\hline BW500R2.5 & & & 2.5 & 483 & 1026 & 9.2 & 92 & 23 & 13.0 \\
\hline GL300R1.5 & \multirow{9}{*}{$\begin{array}{l}\text { Gladstone } \\
\text { (GL) }\end{array}$} & \multirow{3}{*}{300} & 1.5 & 622 & 1321 & 11.0 & 95 & 45 & 24.0 \\
\hline GL300R2.0 & & & 2.0 & 623 & 1323 & 10.5 & 94 & 39 & 22.0 \\
\hline GL300R2.5 & & & 2.5 & 623 & 1324 & 10.2 & 94 & 34 & 20.0 \\
\hline \multirow{3}{*}{$\begin{array}{l}\text { GL400R } 1.5 \\
\text { GL400R2 } 2.0 \\
\text { GL400R2.5 }\end{array}$} & & & 1.5 & 546 & 1161 & 9.5 & 98 & 58 & 26.0 \\
\hline & & 400 & 2.0 & 548 & 1164 & 8.0 & 96 & 47 & 25.0 \\
\hline & & & 2.5 & 548 & 1165 & 7.7 & 97 & 42 & 24.0 \\
\hline GL500R1.5 & & & 1.5 & 471 & 1000 & 6.5 & 100 & 64 & 30.0 \\
\hline GL500R2.0 & & 500 & 2.0 & 475 & 1005 & 5.7 & 99 & 62 & 29.6 \\
\hline GL500R2.5 & & & 2.5 & 475 & 1005 & 4.8 & 97 & 53 & 27.9 \\
\hline CL300R1.5 & & & 1.5 & 663 & 1408 & 12.3 & 91 & 30 & 17.0 \\
\hline CL300R2.0 & & 300 & 2.0 & 663 & 1410 & 11.5 & 89 & 28 & 16.0 \\
\hline CL300R2.5 & & & 2.5 & 664 & 1411 & 11.5 & 92 & 27 & 14.0 \\
\hline CL400R1.5 & & & 1.5 & 601 & 1277 & 9.0 & 92 & 35 & 21.0 \\
\hline CL400R2.0 & Collie (CL) & 400 & 2.0 & 602 & 1279 & 9.0 & 93 & 30 & 19.6 \\
\hline CL400R2.5 & & & 2.5 & 602 & 1280 & 9.0 & 92 & 28 & 18.3 \\
\hline CL500R1.5 & & & 1.5 & 539 & 1145 & 7.0 & 98 & 43 & 25.8 \\
\hline CL500R2.0 & & 500 & 2.0 & 540 & 1148 & 7.0 & 98 & 41 & 25.1 \\
\hline CL500R2.5 & & & 2.5 & 541 & 1150 & 7.0 & 98 & 36 & 22.7 \\
\hline
\end{tabular}




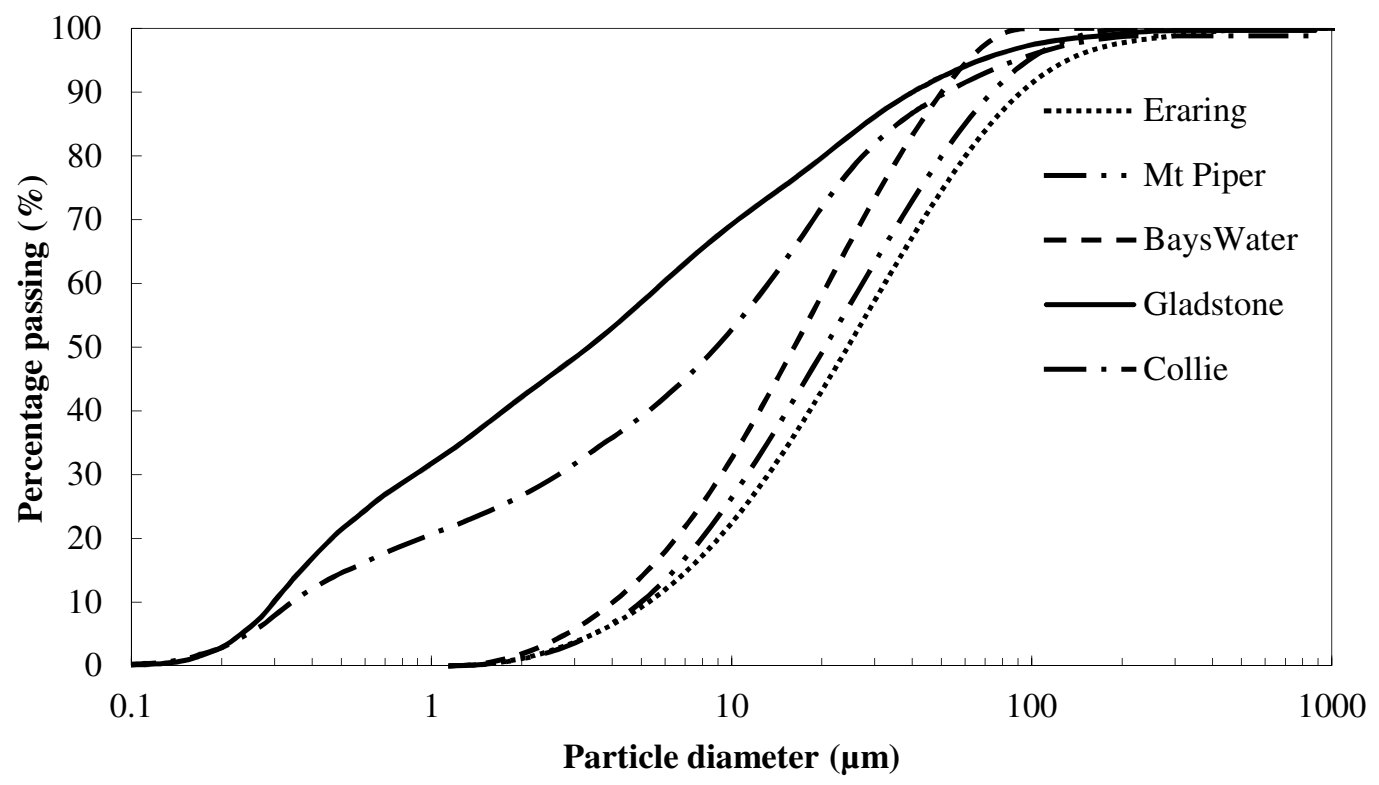

Figure 1 Particle size distribution of the fly ash samples 


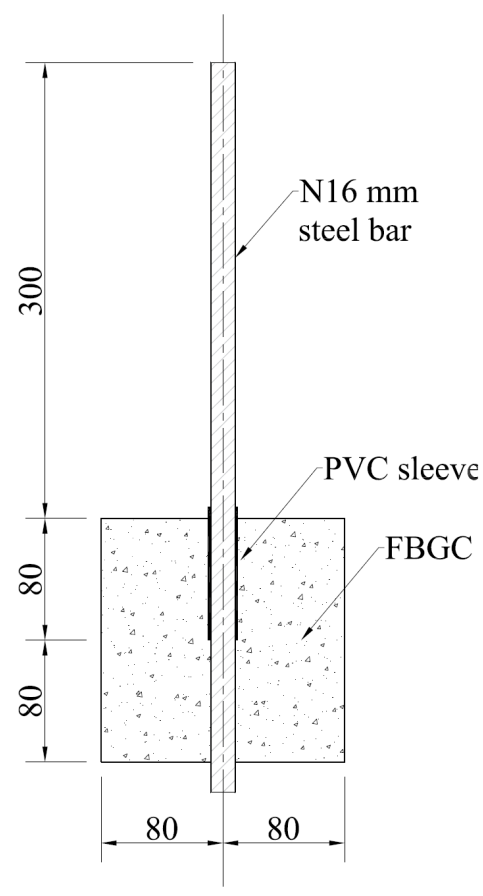

Figure 2 Details of the bond strength test specimen

(All dimensions are in $\mathrm{mm}$ ) 


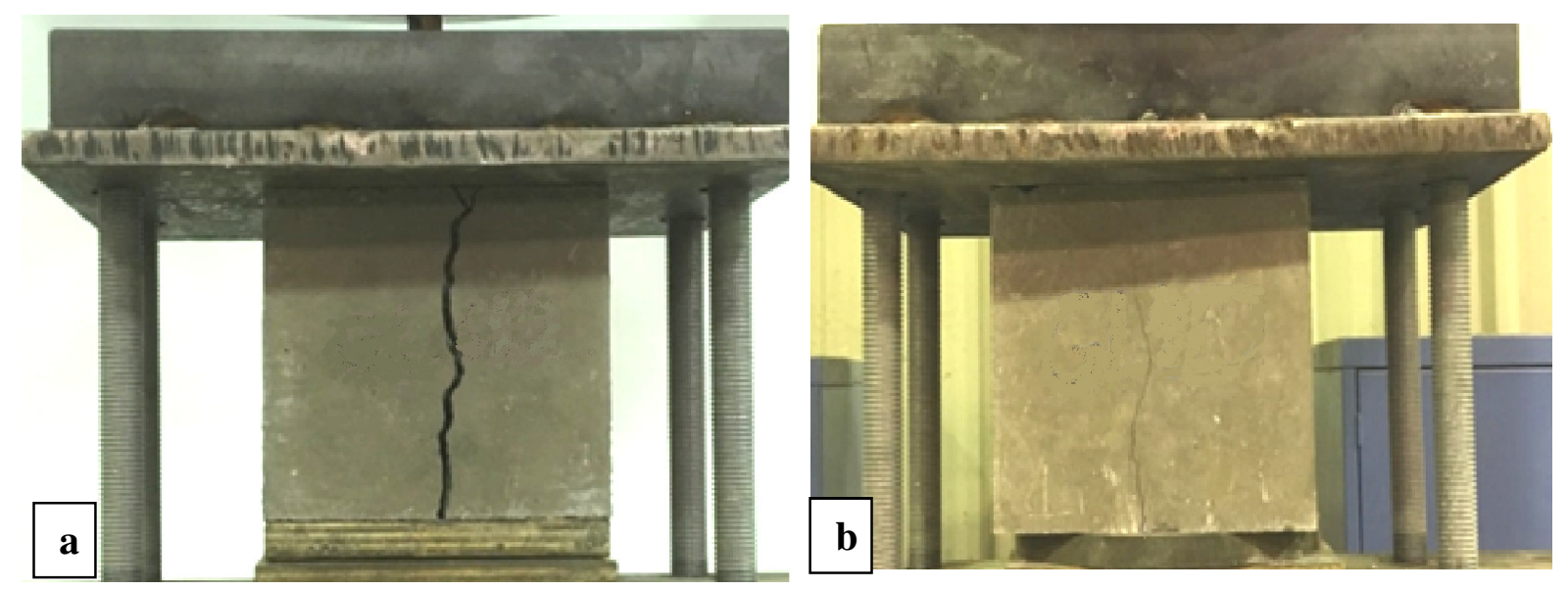

Figure 3 Typical splitting failure of the pull-out test specimens (a) Mix GL500R2.0, (b) Mix 589 GL300R2.0 


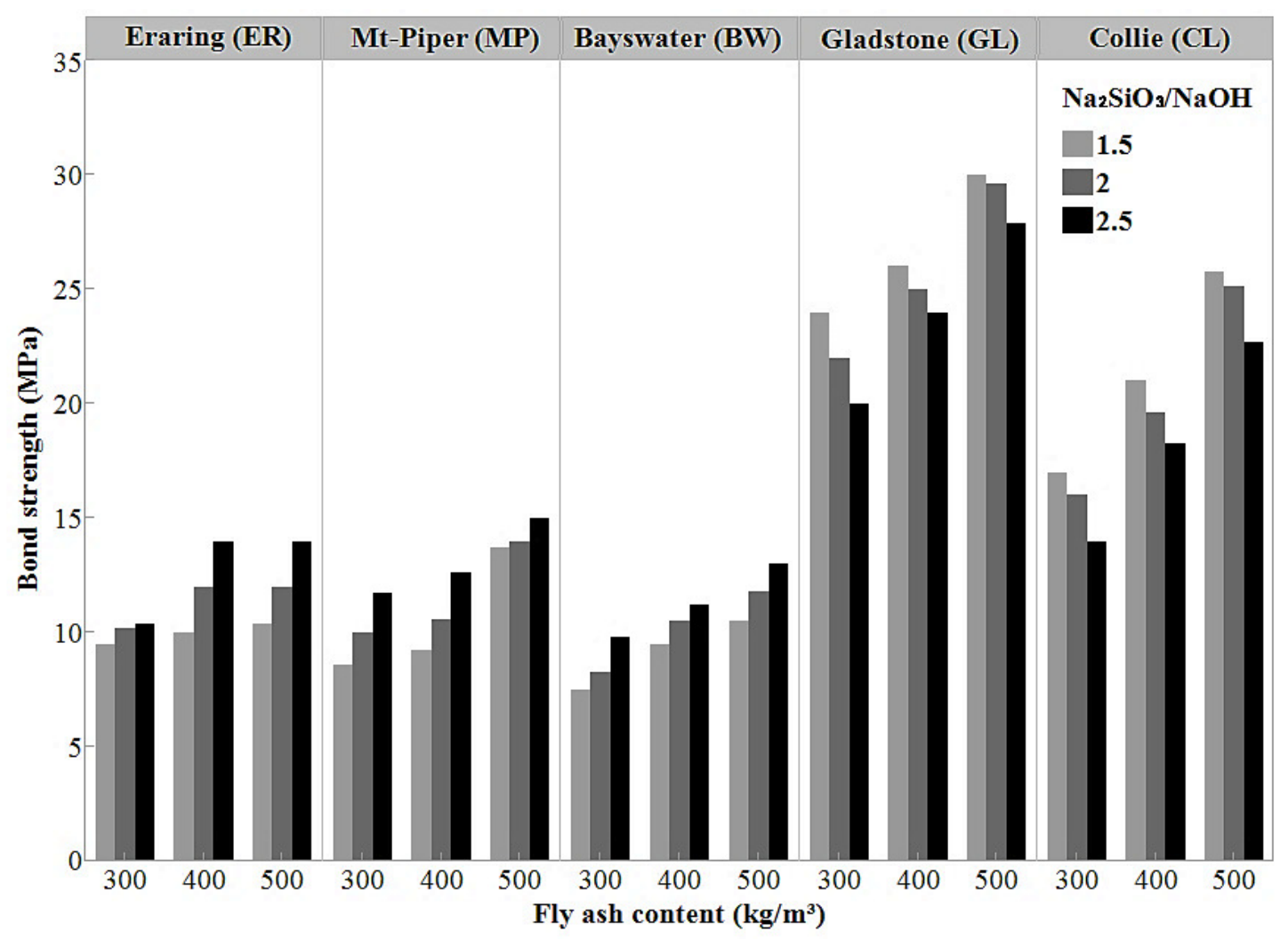

Figure 4 Variation of the bond strength with fly ash content of the FBGC mixes at 591 different $\mathrm{Na}_{2} \mathrm{SiO}_{3} / \mathrm{NaOH}$ ratios 

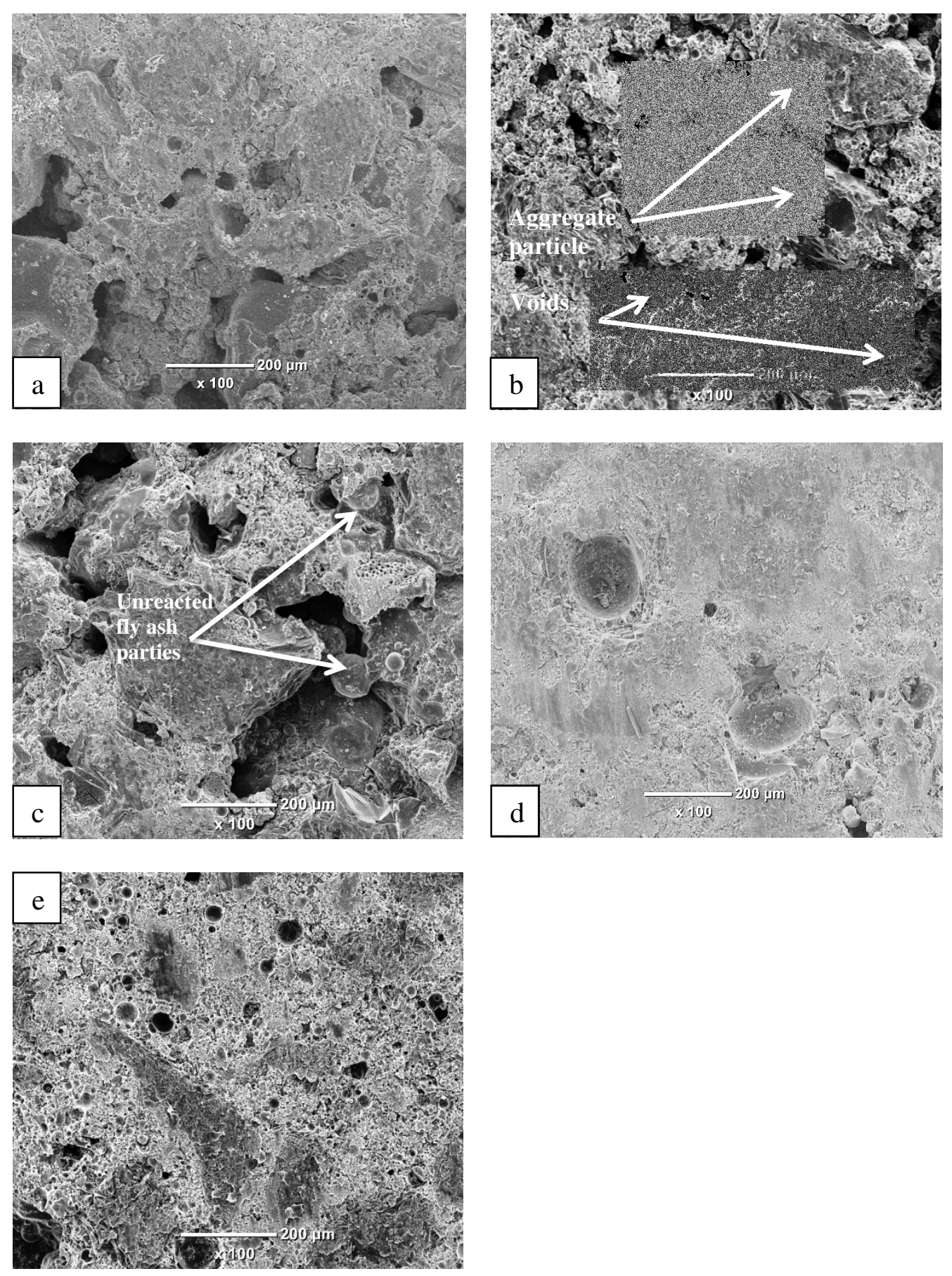

Figure 5 SEM images of FBGC for Mixes (a) ER500R2.5, (b) MP500R2.5, (c) BW500R2.5, (d) GL500R1.5, (e) CL500R1.5 

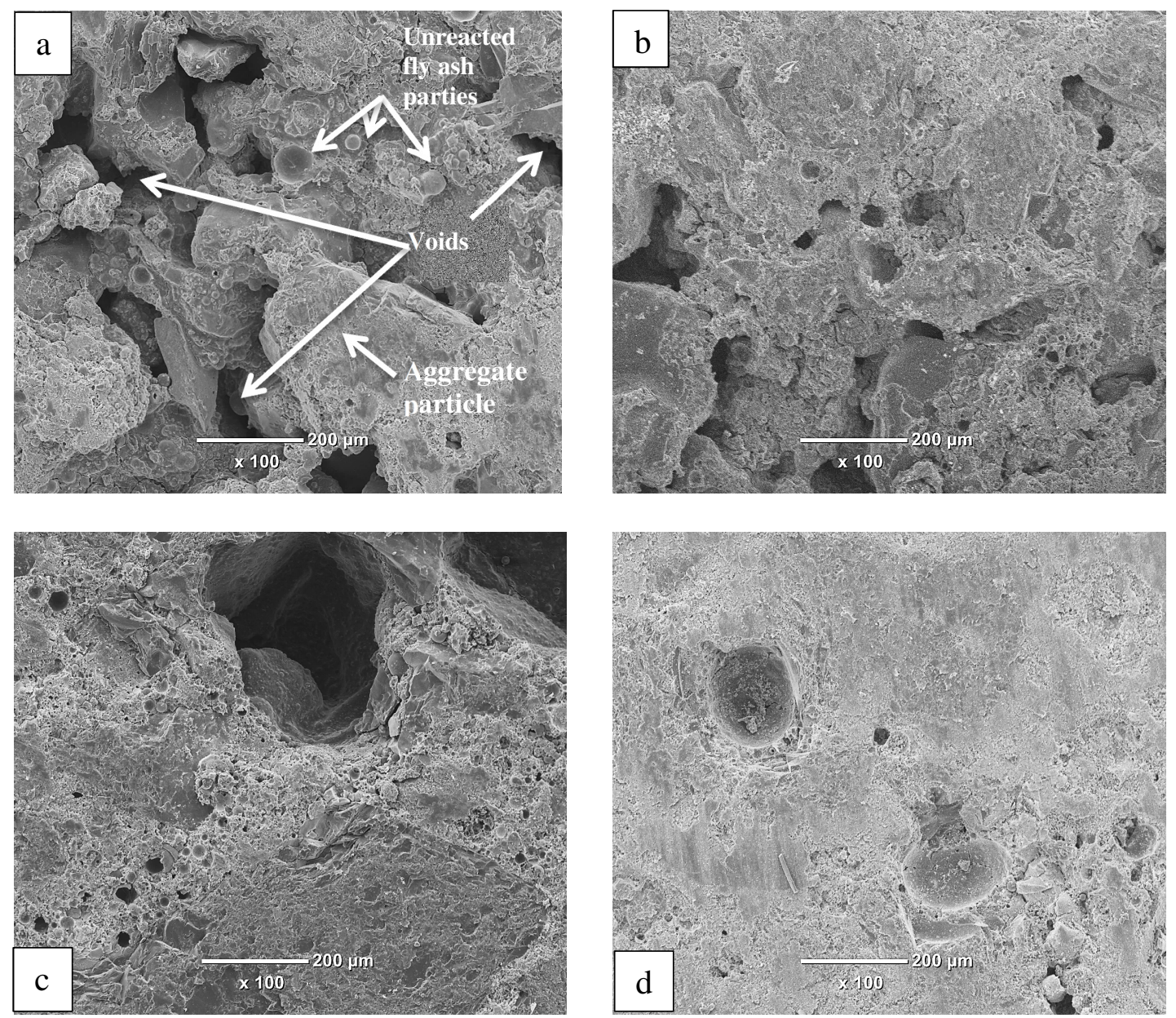

Figure 6 The SEM images for Mixes; (a) ER300R2.5, (b) ER 500R2.5, (c) GL300R1.5 and (d) GL 500R1.5 


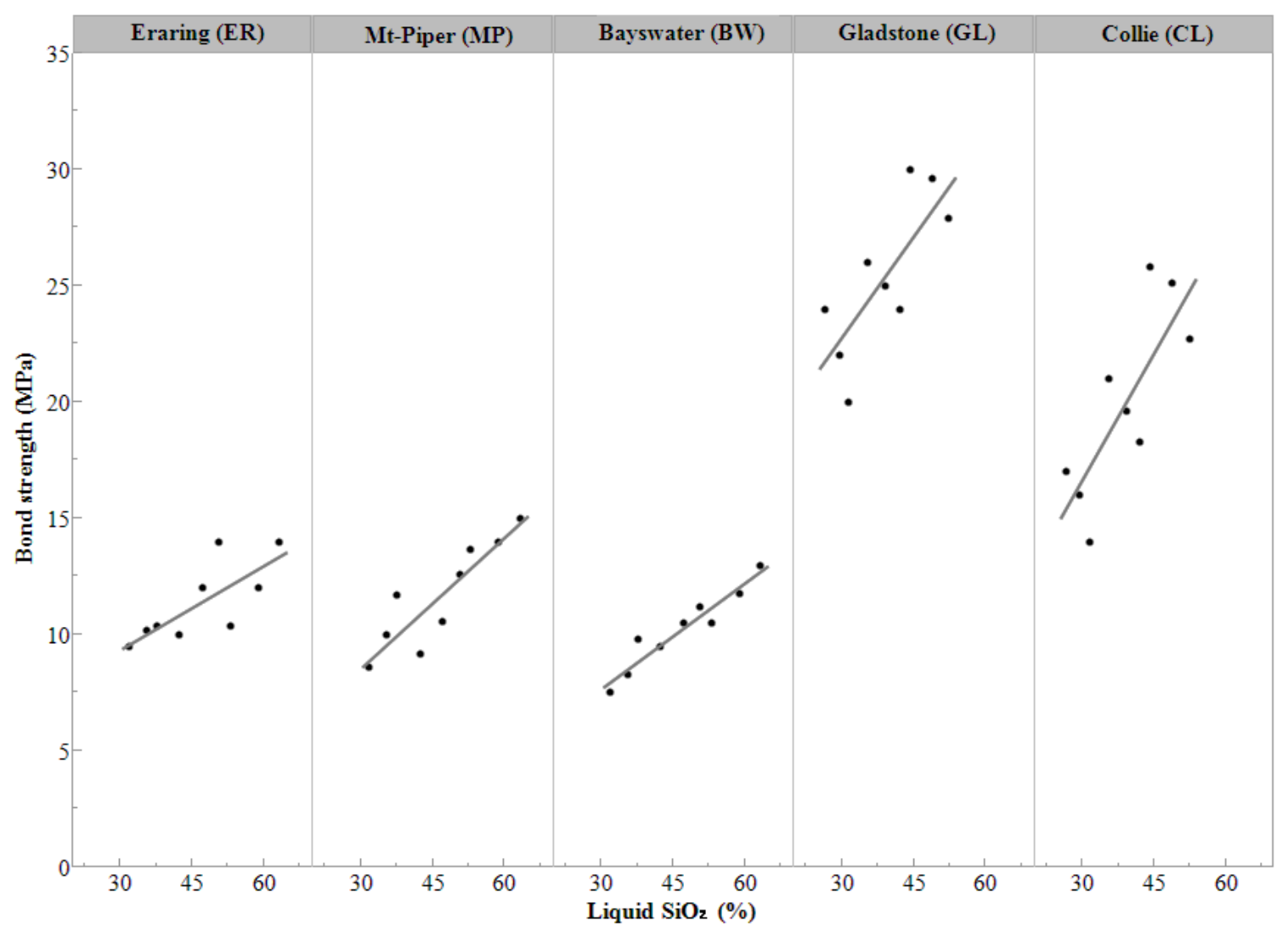

Figure 7 Relationship between the liquid $\mathrm{SiO}_{2}$ and the bond strength of the FBGC 


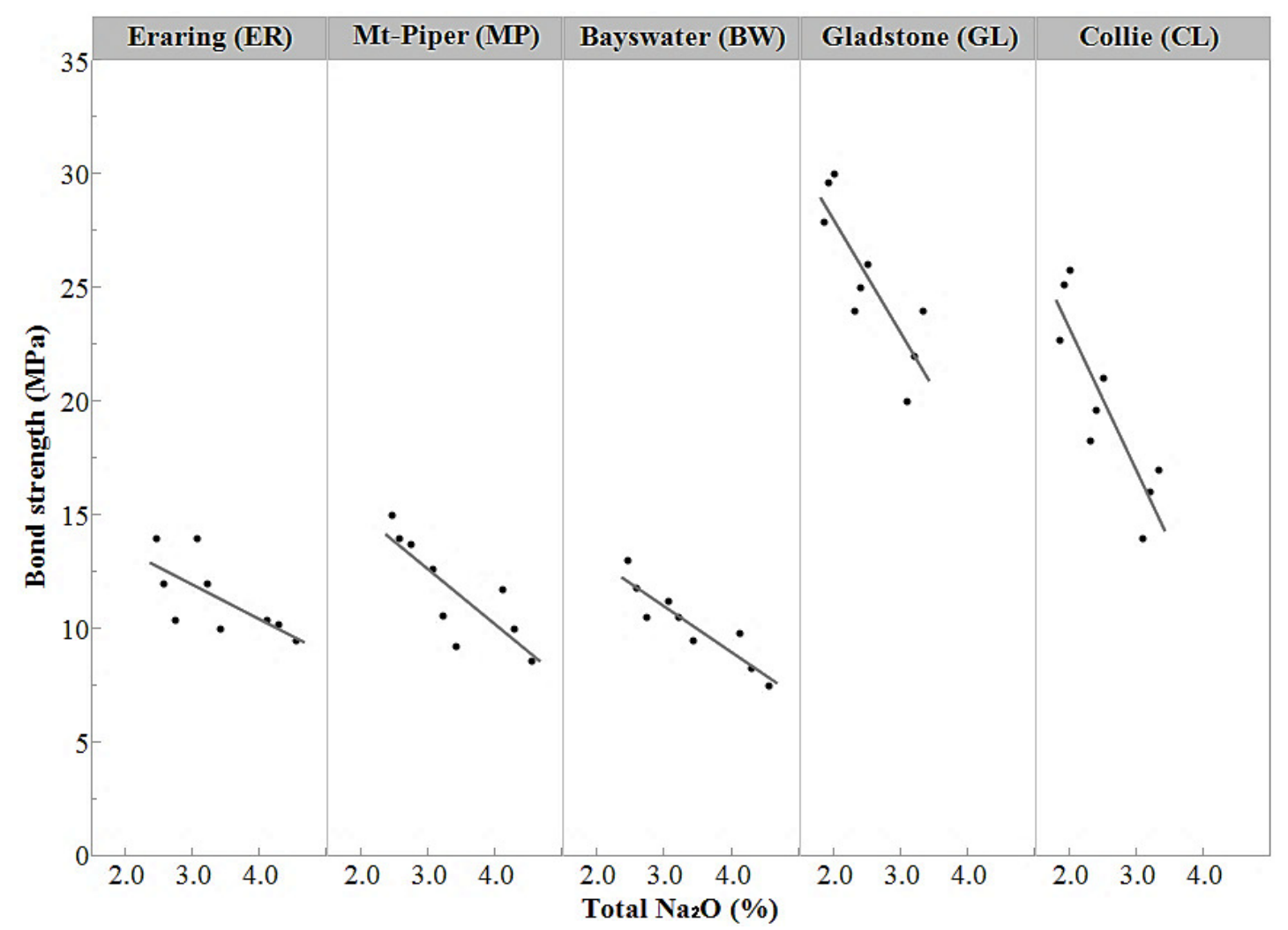

596

Figure 8 Relationship between the total $\mathrm{Na}_{2} \mathrm{O}$ and the bond strength of the FBGC 


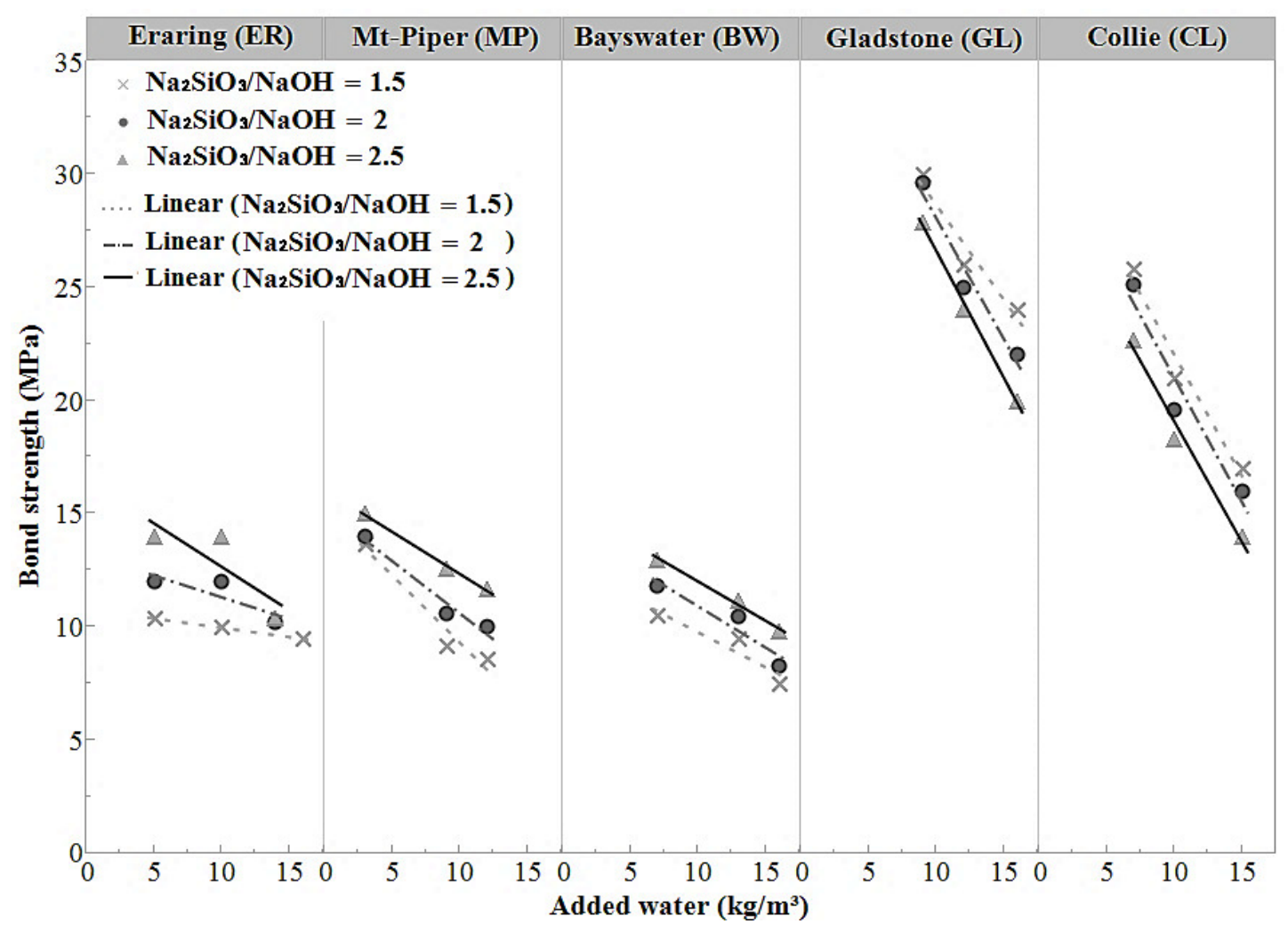

Figure 9 Relationship between the added water and the bond strength of the FBGC 


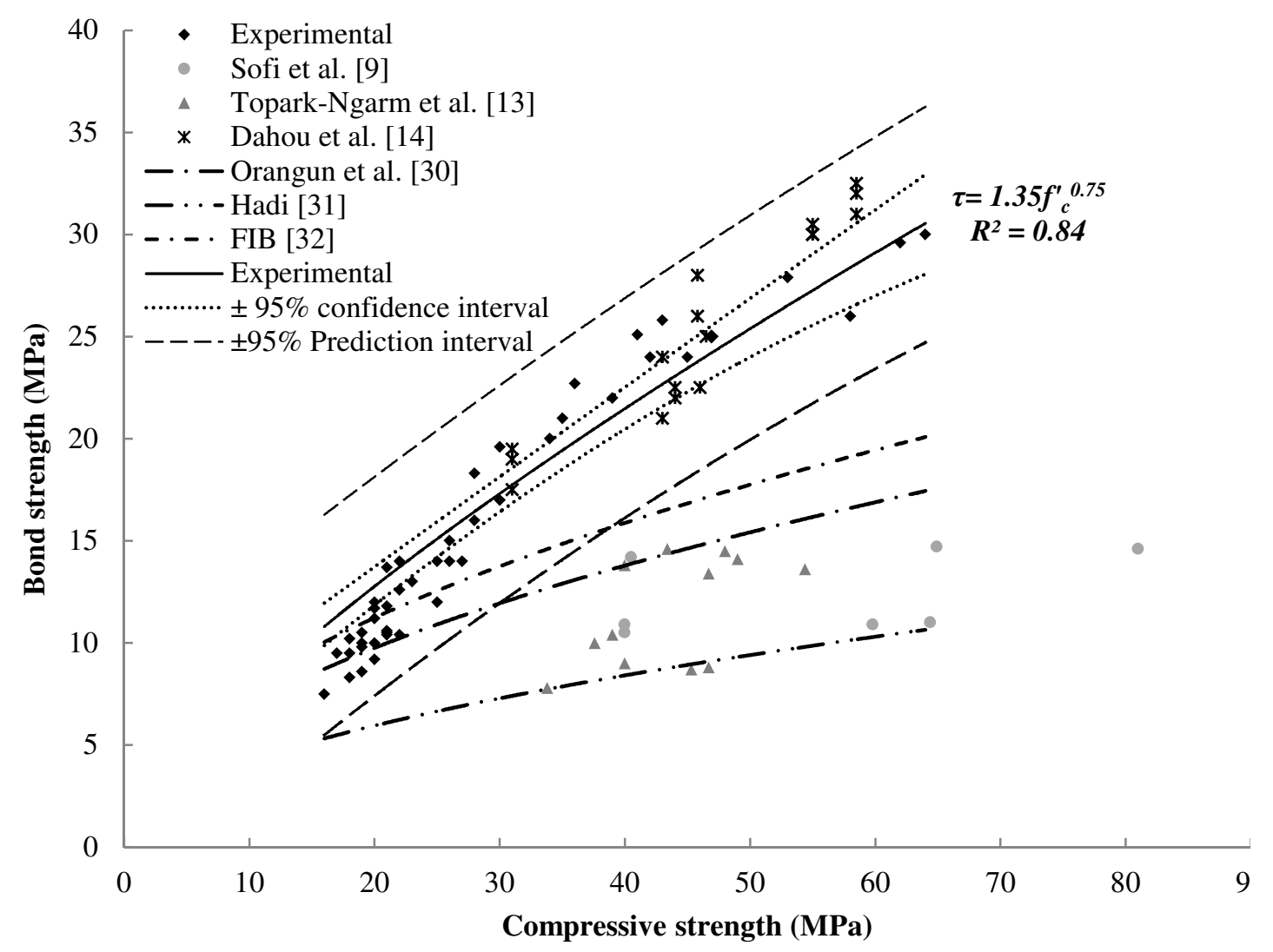

Figure 10 Bond strength of the FBGC versus the compressive strength 